\title{
CLASSIFICATION OF THE LANDFORM UNITS SUPPORTED BY GEOMORPHOMETRIC ATTRIBUTES
}

\author{
classificação das unidades de relevo através de parâmetros geomorfométricos \\ Romário Trentin * \\ Luis Eduardo de Souza Robaina **
}

\begin{abstract}
Resumo
O presente trabalho é um estudo das caracterísitcas das encostas que compõem o relevo na bacia do rio Ibirapuitã, no oeste do Rio Grande do Sul. A classificação do relevo segue uma proposta de mapeamento automatizado apresentado por Silveira \& Silveira (2013). A classificação ocorre pelo cruzamento de informações e atributos topográficos gerados em SIG e hierarquizado através de uma árvore de decisão, usando parâmetros de altitude, declividade, forma em plano e perfil da encosta. Foram identificadas 12 unidades de relevo representativas na bacia. O produto cartográfico obtido sugere que a metodologia é apropriada para caracterizar as encostas na área de estudo e a distribuição espacial dos processos que ocorrem na superficie. Portanto, tem grande potencial para suportar trabalhos relacionando relevo com outros atributos ambientais e o uso do solo.
\end{abstract}

Palavras-chaves: Geomorfometria; Relevo; Ibirapuitã.

\begin{abstract}
This paper presents a study of the characteristics of the slopes that make up the relief in the Ibirapuitã River basin in the west of Rio Grande do Sul. The relief classification follows a geomorphometric automated mapping proposal presented by Silveira \& Silveira (2013). The classification is performed by means of crossing information and topographic attributes generated by GIS and in a hierarchical decision tree. The crossing of information using the decision tree with the parameters of altitude, slope, curvature profile and plan identified 12 representative units in the basin. The cartographic product obtained suggests that the methodology is appropriate to characterize the slopes in study area and the spatial distribution of processes, with great potential for support in work relating the relief characteristics with other environmental attributes and land use.
\end{abstract}

Key words: Geomorfometry; Relief; Ibirapuitã.

\section{Résumé}

Ce travail est une étude des caractéristiques des pentes qui composent le relief dans le bassin de la rivière Ibirapuitã dans l'ouest de Rio Grande do Sul. La classification du relief suite à une proposition de cartographie automatisée présentée par Silveira \& Silveira (2013). La classification est l'intersection de l'information et des attributs topographiques générés en SIG et hiérarchisés, par un arbre de décision, en utilisant des paramètres d'altitude, la pente, plat et profil de la pente. Ils ont identifié 12 unités du relief représentatives dans le bassin. Le produit cartographique obtenu suggère que la méthodologie est appropriée pour caractériser les pentes et la distribution spatiale processus de surface, dans la zone d'étude. Donc il y a un grand potentiel pour soutenir la recherche concernant le relief avec d'autres caractéristiques environnementales et l'utilisation des terres.

Mots-Clés: Geomorfometria; Relief; Ibirapuitã.

(*) Prof. Dr. da Universidade Federal de Santa Maria - Av. Roraima, 1000, Prédio 17, Sala 1113c, CEP:97105-900, Santa Maria (RS), Brasil. Tel: (+55 55) 3220-8639 - romario.trentin@gmail.com

(**) Prof. Dr. da Universidade Federal de Santa Maria - Av. Roraima, 1000, Prédio 17, Sala 1113c, CEP:97105-900, Santa Maria (RS), Brasil. Tel: (+55 55) 3220-8639 - lesrobaina@yahoo.com.br 


\section{INTRODUCTION}

The parameterization of the relief by means of GIS is the process of extracting quantitative attributes of the topography. According to Muñoz (2009), it quantitatively describes the Earth's surface forms by means of equations applied to numerical models of altimetric representation.

Current classification methods allow the subdivision of shapes into relief elements, which are a set of portions of a type of relief relatively homogeneous in relation to the profile, gradient, orientation, and placement in the landscape (MACMILLAN AND SHARY, 2009).

This paper presents a study of the characteristics of the slopes that make up the relief in the Ibirapuitã River basin in the west of Rio Grande do Sul. The basin is emphasized for defining the relief sculpturing and, in the words of Botelho (1999), "since the river basin is delimited considering geomorphological criteria, it has some advantage over the other planning units defined by other attributes, which present imprecise limits, such as those based on the types of vegetation or climate characteristics".

Similarly, authors like Christofoletti (1980), Beltrame (1994) and War and Cunha (1996, 2003) state that the river basin, comprehends part of a joint vision of the behavior of natural conditions and human activities, since significant changes in any one of these units can generate changes or even impacts to the downstream and to the energy flows.

The national water resources policy through the law 9.433 of January 8, 1997 creates the National System of Water Resources Management and in the item V of Article 1 emphasizes that the river basin is the territorial unit for implementation of the National Water Resources Policy and actions of the National System of Water Resources Management (BRAZIL, 2013).

Therefore, it can be said that the studies on river basins are associated with the notion of system, including the headwaters, watershed, hierarchical drainage system, where every occurrence of events, of anthropogenic or natural origin, interferes with the dynamics of this system. That is, it is understood that the drainage basins are treated as geographical units where natural resources are integrated.

To characterize the slopes of the basin a quantitative analysis through geomorphometric parameters (geomorphometry) or digital analysis of the relief was carried out (SILVEIRA et al., 2013). MDT derived attributes are understood here as topographic attributes (MOORE et al, 1991 and 1993; WILSON \& GALLANT, 2000; CHAGAS, 2006; SILVEIRA et al, 2012; SILVEIRA et al, 2013), which, however, in the literature appear under different names, as parameters of the landforms (SPEIGHT, 1968), morphometric variables (SHARY el al., 2002), geomorphometric variables (BISHOP et al., 2009), land attributes (PENNOCK, 2003; CATEN, 2009), geomorphometric attributes (SCHMIDT \& DIKAU, 1989), relief attribute (IPPOLITI et al., 2005; SIRTOLI et al., 2008).

Several authors (ARGENTO 1994; BOTELHO, 1999; XAVIER DA SILVA, 2005) point to the increasing use of Geographic Information Systems (GIS) in the relief and environmental studies.

Topographic attributes can be parameterized from variables such as altitude, slope, aspect, different curvatures (in plan, profile, etc.), contributing area, topographic moisture index, etc. (MCBRATNEY et al., 2003, SILVEIRA et al., 2013).

Franklin and Peddle (1987) define five basic parameters to relief parameterization: i) elevation, ii) gradient, iii) orientation iv) curvature, represented by the concavity/convexity relief, v) roughness.

\section{STUDY AREA LOCATION}

This study was conducted through geoprocessing techniques associated with relief digital analysis determining the parametric representation of the relief forms, with the use of topographic attributes obtained from a Digital Elevation Model, developing a geomorphometric compartmentalization in the form of a zoning of the aspects that make up the relief in the basin of Ibirapuitã River, located in western Rio Grande do Sul (RS), with an area of 7978.70 square kilometers (Figure 1). 

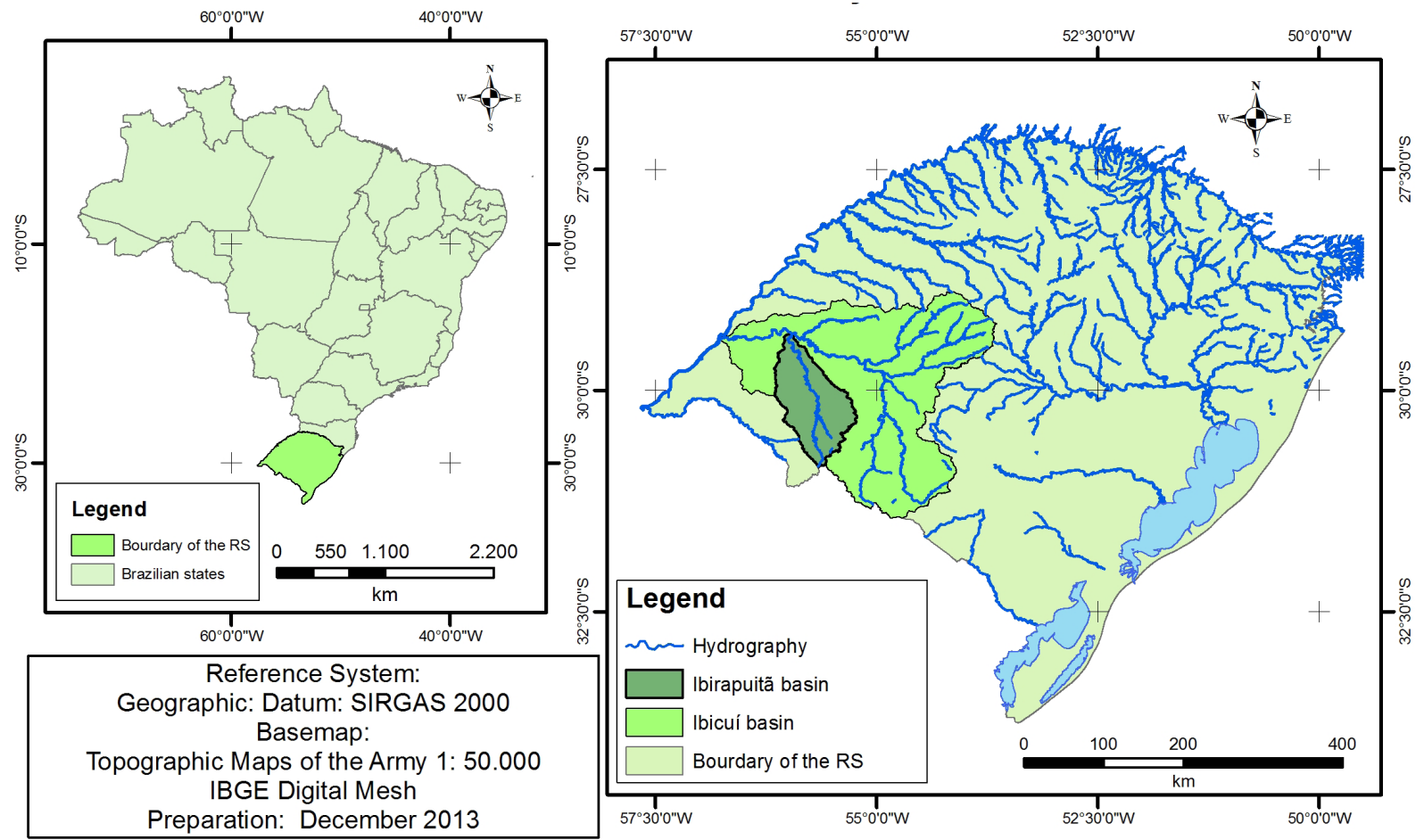

Figure 1 - Ibirapuitã River basin location map

\section{METHOD}

The relief classification of the Ibirapuitã River basin follows a geomorphometric automated mapping proposal presented by Silveira \& Silveira (2013), which was supported by the precepts of Iwahashi and Pike (2007). The classification is performed by means of crossing information and topographic attributes generated by GIS and in a hierarchical decision tree based on preset values, based on knowledge of the area. Four topographic attributes were used: altitude, gradient, slope shape in plan and profile.

As a cartographic basis, the army topographic maps at 1: 50,000 scale were used, from which the information of the level curves was extracted, with 20 meters equidistance added to the quoted points present in the area. Through the points, the interpolation of these altimetric information was performed using the ANUDEM interpolator (HUTCHINSON, 1989, 1996, 2008), available as a tool in the ArcMap application version 10.1 (ESRI, 2013), which creates a digital elevation model hydrologically consistent.

The first parameter used considered the amplitude variations presented by the basin due to the distribution of the frequency histogram, where the overall average of altimetries was considered, corresponding to 158 meters that divided the slopes located in high and low altitude.

The slopes can be defined in a simplified form as an element of the surface inclined in relation to the horizontal, which has a gradient and an orientation in space (VELOSO, 2002), and thus can be classified according to their gradient, curvature on plan and profile.

The information of declivities generated by the DTM was obtained in this work through the Horn polynomial (1981) and was separated into two classes whose limit is $5 \%$.

The analysis of the slope in the plan, corresponds to the variation of the cambering gradient in orthogonal direction on the slope (curvature of the surface perpendicular to the direction of inclination) and refers to the divergent /convergent character of the terrain and the curvature profile is the cambering gradient variation rate in the direction of its orientation (the curvature of the surface on the inclination) and is related to the convex/concave character being decisive in the acceleration or deceleration of the water flowing over it. Both were obtained by DTM through the use of the 
Zevenbergen and Thorne polynomial (1987).

The profile of the slopes, in a GIS environment is analyzed according to its curvature value (frequency histogram) and theoretically, rectilinear slopes have null curvature value, concave slopes have positive and convex slopes have negative value (VALERIANO, 2003).

However, slopes with null values are very rare in nature, so, very little of what is thought to be rectilinear really presents null curvature value, and presents values that belong to a tolerance range in the vicinity of that value instead.

The classification of the slopes plan, in a GIS environment is analyzed according to its frequency histogram that indicates the value of that curve. Similar to the profile, null values correspond to lack of curvature corresponding to flat sides, and the positive values represent divergent curvature and negative values correspond to convergent curvature.

By crossing information using the decision tree shown in Figure 2, 12 units have been identified.

\section{RESULTS}

The Ibirapuitã river corresponds to one of the main tributaries of the Ibicuí river, one of the most important of the western Rio Grande do Sul.

The basin is of 7 th order with area of $7978,70 \mathrm{~km}^{2}$ and perimeter of $646120 \mathrm{~km}$ (Figure 3). The extension of the main channel of $597,72 \mathrm{~km}$ flowing from south to north forming a pattern of rectangular drainage controlled by structures in the volcanic rocks substratum.

The main tributaries are: in the right margin the Caverá and Ibirapuitã Chico rivers and in the left margin the Pai-Passo and Inhanduí rivers.

Geomorphologically these basin is included according to Robaina et al (2010) on the Plateau of the Serra Geral, specifically the portion called Plateau of the Campanha.

In general, the relief of the basin consists predominantly of hills, characterized by slopes with range around $40 \mathrm{~m}$ and declivities between $5 \%$ and $8 \%$. Also forms of buttes with flat top occur with amplitudes of 20 to $60 \mathrm{~m}$ and declivities greater than $30 \%$ and hills with amplitudes of 120 to $160 \mathrm{~m}$.

In the watersheds to the south and west it is formed by rolling hills with buttes associated and to the east it consists of a range of buttes and hills known as Sierra of the Caverá.

The downstreams areas have a flat relief forming large slopes with declivities inferior to $5 \%$.

The basin slopes were divided into 12 units, based on the average altitude, the declivities of $5 \%$ and the shape on profile and plane.

The first six units correspond to the upper course and the last six units to the middle and lower course of the basin. Figure 4 shows the diagram representing the occurrence and distribution of slopes units in the basin of Ibirapuitã River.

In Units I, II and III the morphogenetic processes of erosion and mass movements are important, constituting portions more dynamically active.

The Unit I represents the portions of slopes where the water flow is convergent characterizing the beginning of the river network and defining a collecting slope. This unit occurs in an area of $653.92 \mathrm{~km}^{2}$, corresponding to $8.2 \%$ of the basin area. It is characterized by declivity greater than $5 \%$ and convergent curvature plan.

Unit II covers $453.84 \mathrm{~km}^{2}$, representing $5.69 \%$ of the total basin area. It is characterized by slopes of the upper course areas, with a predominance of morphogenetic processes of erosion due to the declivity greater than $5 \%$ and concave profile. It is spatially located in the middle slope between the valleys of the drainage channels, especially in the areas of water dispersion.

Unit III covers approximately $461,58 \mathrm{~km}^{2}$, being $5.79 \%$ of the total basin area. It represents slopes of the upper course areas, with the flow rate increasing toward the bottom of the slope, and divergent flow that can induce the formation of various erosional channels in the lower third of the slope. 


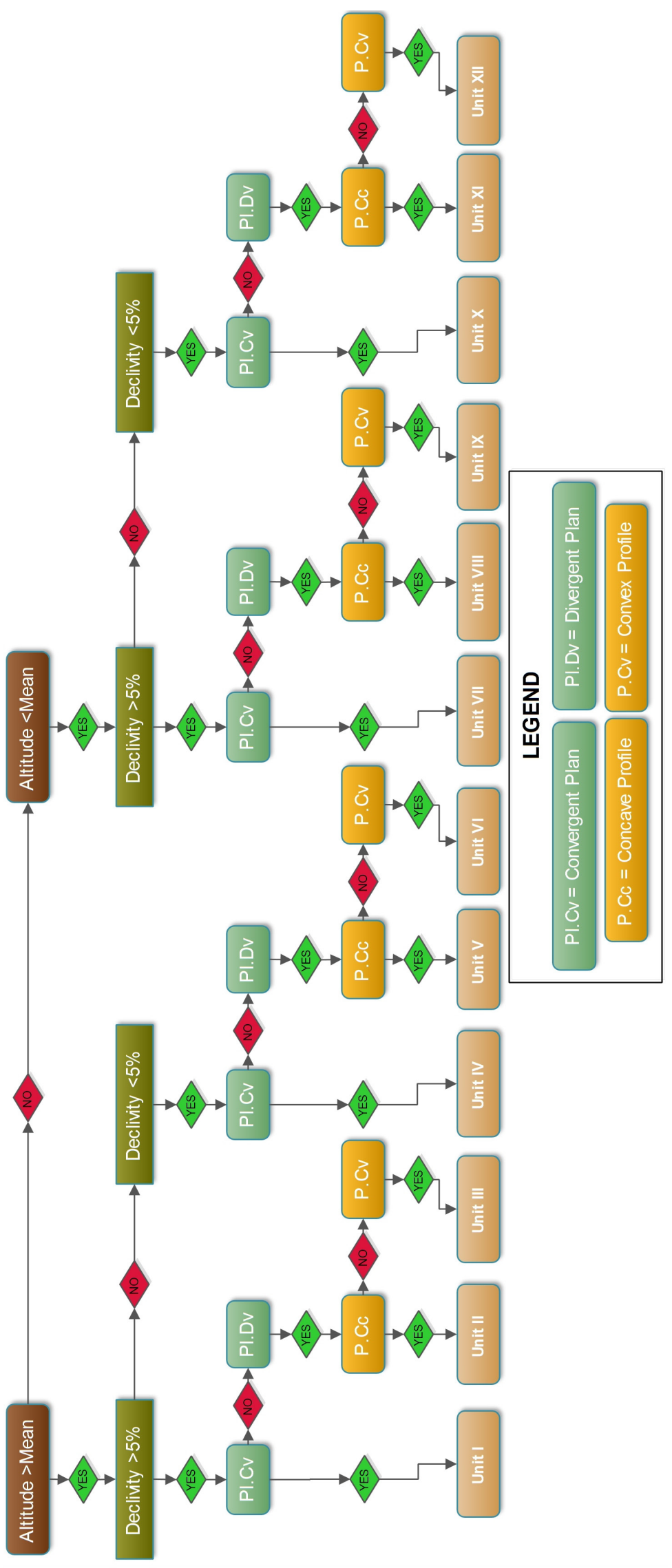

Figure 2 - Decision tree used to define the units geomorphometric 


\section{Map of the Hydrographic Network Ibirapuitã Basin}

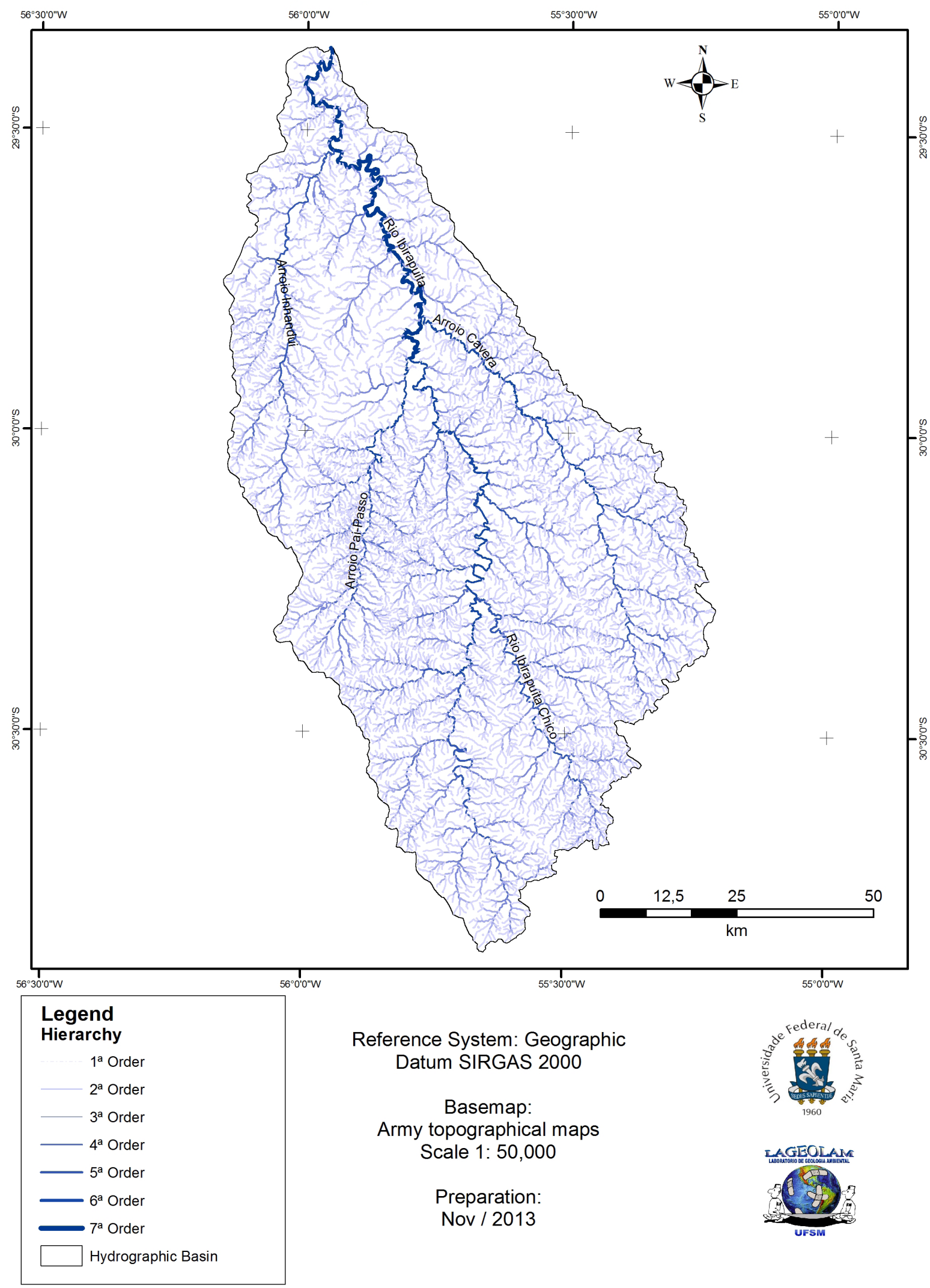

Figure 3 - Map of the hydrographic network Ibirapiutã basin 


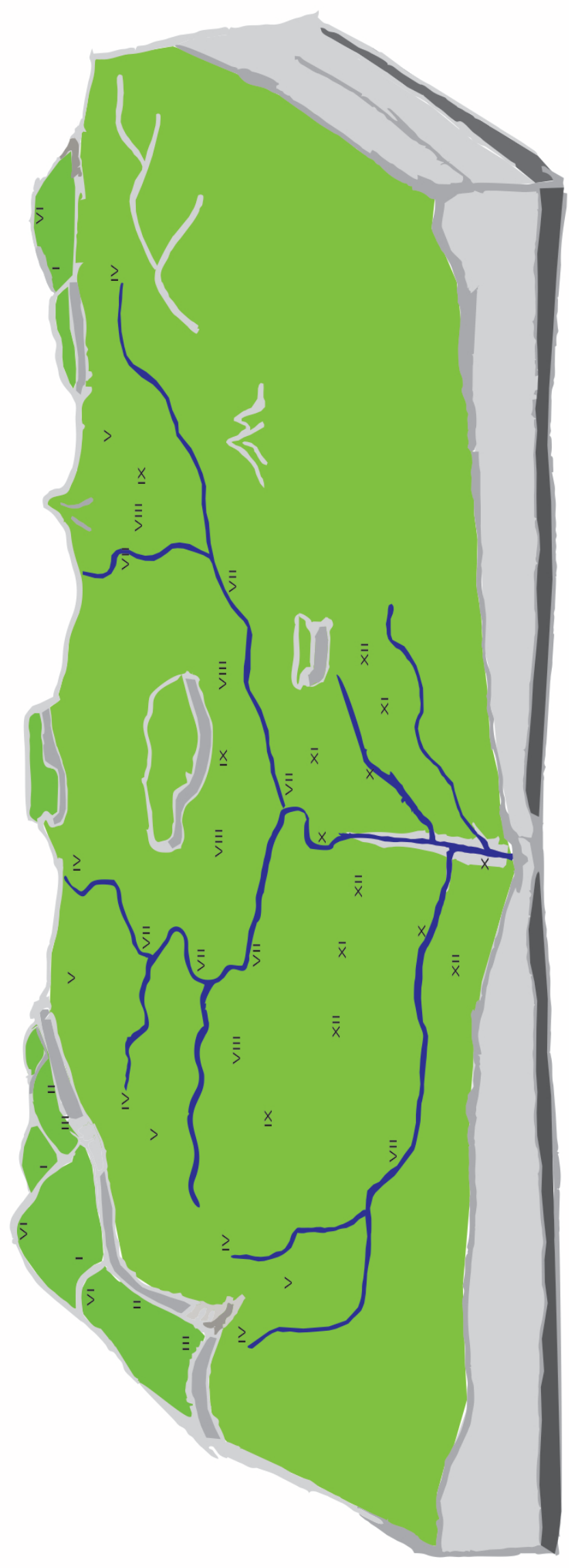

Figure 4 - Diagram representing the occurrence and distribution of slopes units in the basin of Ibirapuitã River. 
Unit IV covers approximately $814.71 \mathrm{~km}^{2}$, corresponding to $10.21 \%$ of the basin area. It is characterized by flat areas in the upstream of the basin (declivity inferior to $5 \%$ but altitudes above the average), with convergent flow that is reflected in wetlands at the sources of the rivers.

It occurs mainly associated to unit I in the more flat portions, spatially positioned in the upper third of the slope. In terms of hydrographic basin, this unit is spatially concentrated in two large areas, one at the southern portion of the basin and the other at the western portion of the basin formed by the watershed of the Inhanduí and Pai-Passo sub-basins.

The unit VI, covers $559.14 \mathrm{~km}^{2}$, representing approximately $7 \%$ of the basin area. It occurs in the upper course of the basin formed by flat areas which are the most elevated areas, spatially positioned on the tops of slopes.

The Figure 5 shows the form of occurrence and distribution of the slope units I to VI, in the Ibirapuitã basin.

The unit VII, located in the middle/lower course of the river basin (altitudes below the average) covers $362.84 \mathrm{~km}^{2}$, representing $4.55 \%$ of the total area. Present gradients that favor the morphogenetic process of erosion due to the declivities higher than 5\% and flow convergence. They occur predominantly at the base of the slopes following the drainage network.

Unit VIII covers $293.03 \mathrm{~km}^{2}$, representing $3.67 \%$ of the total of the hydrographic basin area. It is characterized by slopes from areas of the middle and lower course with a predominance of the middle course of the hydrographic basin. There is a predominance of morphogenetic processes of erosion in the superior portions of the slope with deposition at the base. Spatially, it is located in the middle portions of the slope, sometimes near the drainage.

The unit IX is relatively less represented in the hydrographic basin with an area of $212.65 \mathrm{~km}^{2}$, corresponding to $2.67 \%$ of the basin area. It is characterized by slopes of the middle and lower course areas (altitudes below the average), with the flow rate increasing toward the bottom of the slope (convex profile) but with divergent flow (divergent plan), which can lead to the formation of small erosion channels in the slope base. They predominate in the areas of the lower third of the slope associated with the floodplains.

The X unit covers $1674.59 \mathrm{~km}^{2}$, corresponding to almost $21 \%$ of the basin area. It is characterized by flat areas, along the middle and lower course drainage channels. It is the unit that occupies the largest area in the basin, which demonstrates the features predominantly of small elevations and declivities inferior to $5 \%$.

Unit XI occupies $1126.86 \mathrm{~km}^{2}$, corresponding to $14.12 \%$ of the basin area. It is characterized by flat areas (declivities inferior to 5\%). The processes range from top to the bottom of this portion of the slope through the decrease on the energy of the divergent flow (concave profile and divergent plan). They occur mainly in the middle slope toward the top, occupying the upper third of the slope.

Unit XII covers approximately $837.48 \mathrm{~km}^{2}$, representing approximately $10.5 \%$ of the watershed area. It occurs in the middle and lower course of the river basin, predominantly in the lower course, composing the main flat areas of the basin in the portions of internal dividers of the sub-basin.

Figure 6 shows the maps with the shape of occurrence and distribution of slopes units VII to XII, in the basin of Ibirapuitã River. 

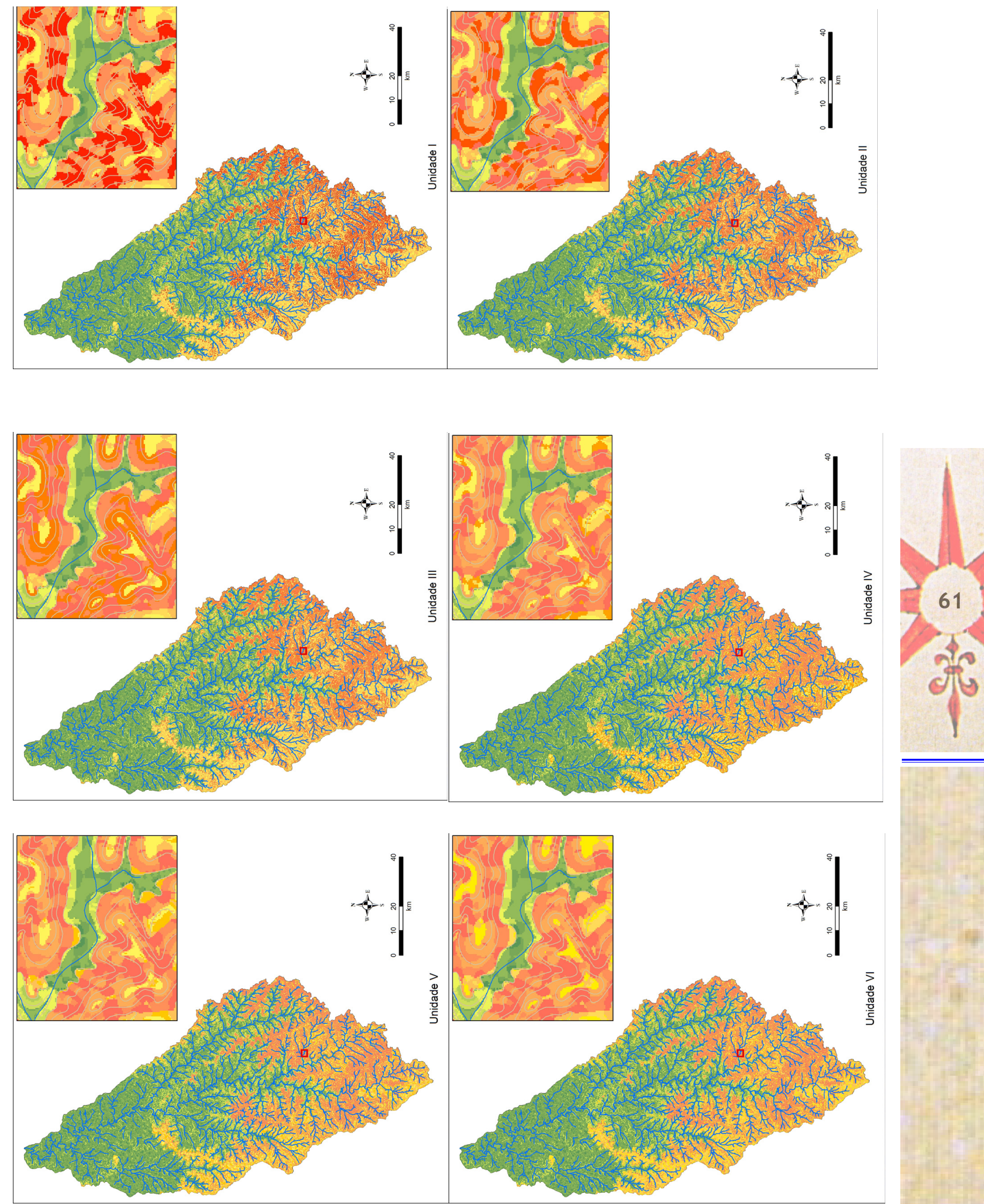

Figure 5 - Units geomorphometric I to VI in the Ibirapuitã basin. 
TRENTIN, R.; ROBAINA, L. E. S.

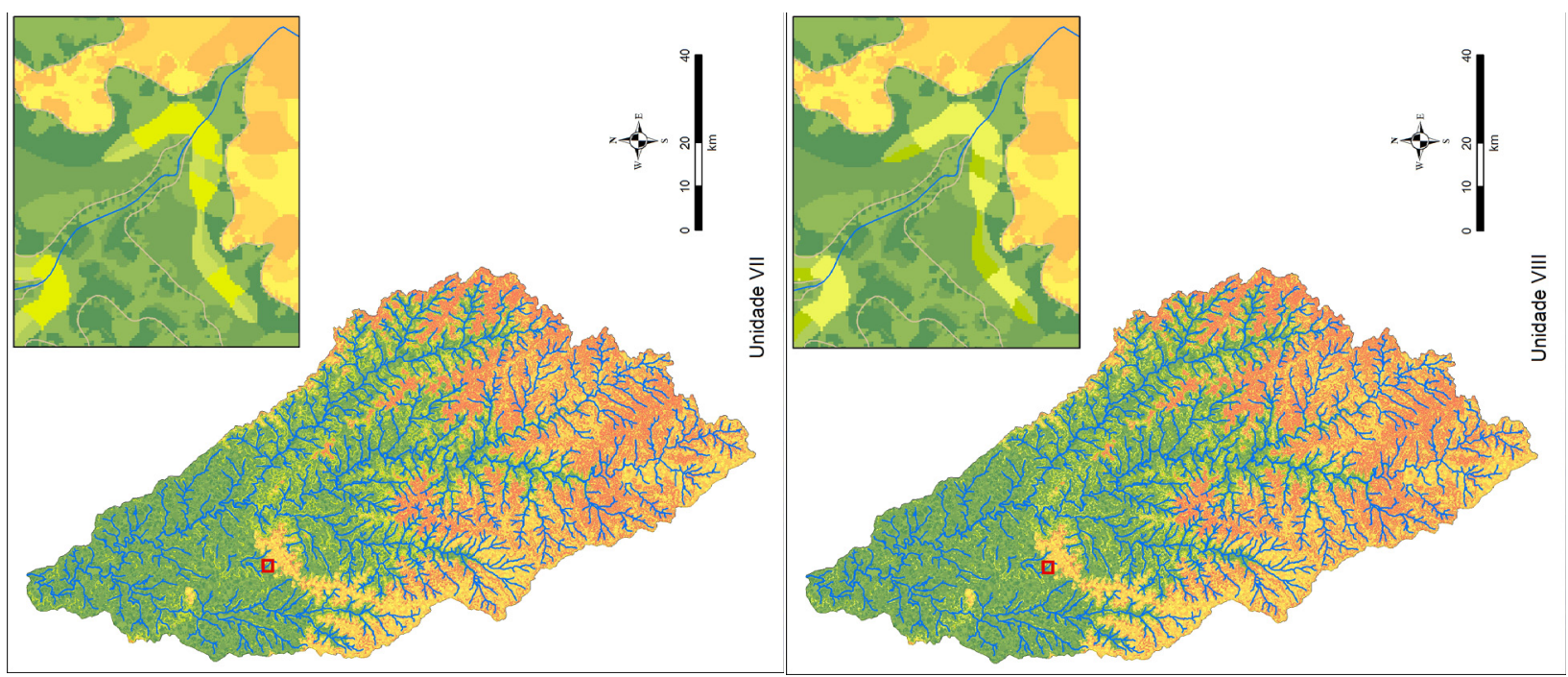

62
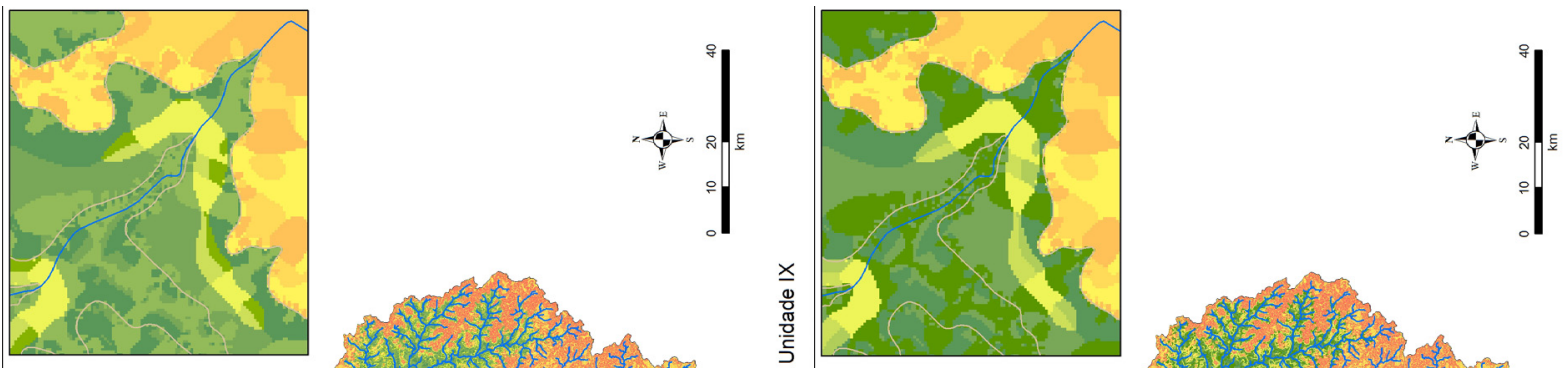

और
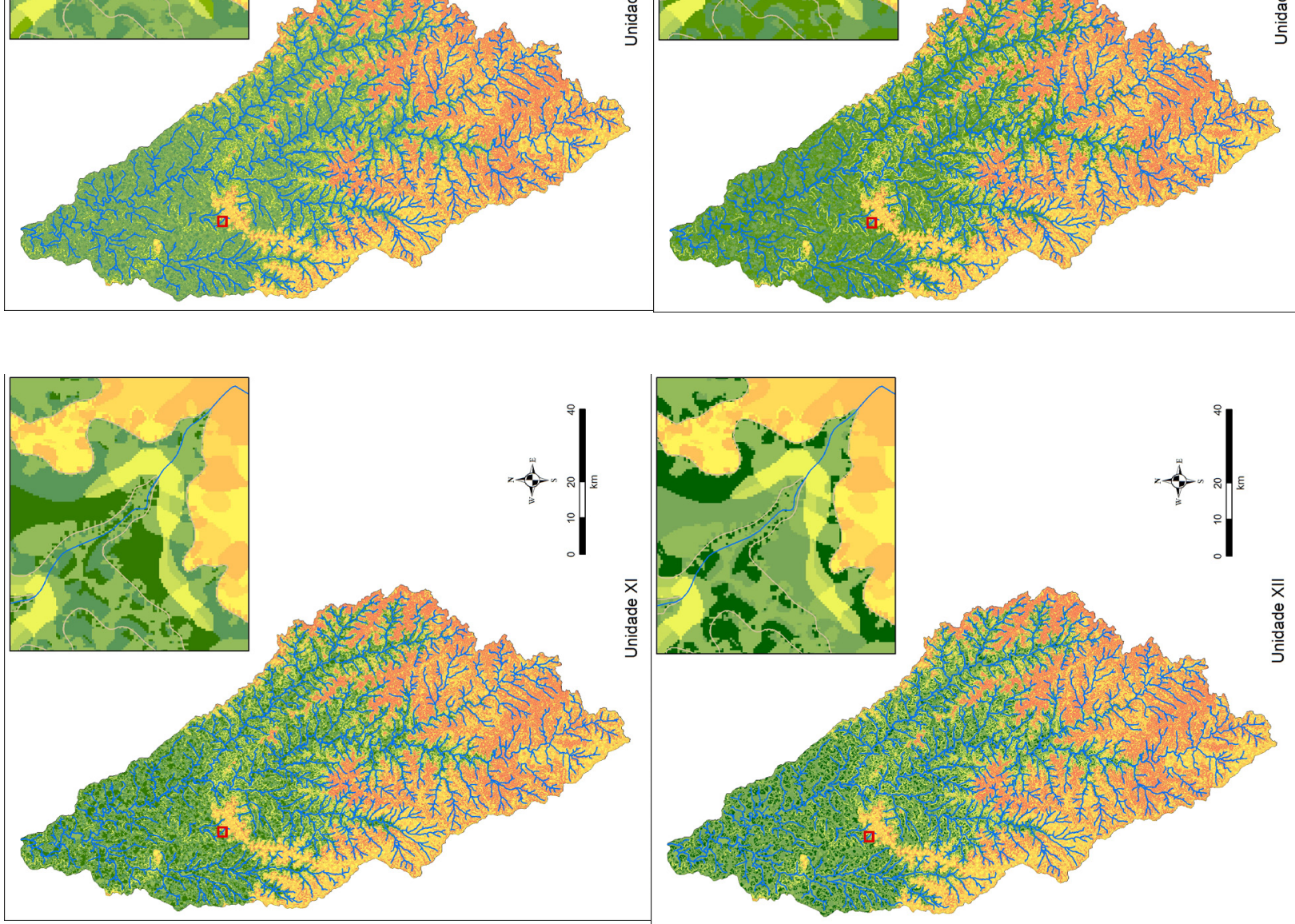

Figure 6 - Units geomorphometric VII to XII in the Ibirapuitã basin. 


\section{FINAL CONSIDERATIONS}

The establishment of criteria with fixed parameters, use of DEMs for variables calculation allows the relief mappings reducing subjectivity to the identification and delineation of features.

The crossing of information using the decision tree with the parameters of altitude, slope, curvature profile and plan identified 12 representative units in the basin of Ibirapuitã River.

As general characteristics, it was found that the basin of Ibirapuitã River has an area of low altitudes and lower declivities inferior to 5\%, which it appears in the definition of the units X, XI and XXI that are those that occupy the largest areas represent about $46 \%$ of the total study area.

The cartographic product obtained suggests that the methodology is appropriate to characterize the slopes in study area and the spatial distribution of processes, with great potential for support in work relating the relief characteristics with other environmental attributes and land use.

\section{BIBLIOGRAPHIC REFERENCE}

ARGENTO, M. S. F. Mapeamento Geomorfológico. In: GUERRA, A. J. T.; CUNHA, S. B (Org.). Geomorfologia uma atualização de bases e conceitos. Rio de Janeiro: Bertrand Brasil, 1994.

BELTRAME, Â. V. Diagnóstico do meio físico de bacias hidrográficas: modelo e aplicação. Florianópolis: Ed. da UFSC, 1994.

BISPO, P. C.; VALERIANO, M. M.; KUPLICH, T. M. Variáveis geomorfométricas locais e sua relação com a vegetação da região do interflúvio Madeira-Purus (AM-RO). Acta Amazônica, v. 39, n. 01, p-81-90, 2009. BOTELHO, R. G. M. Planejamento ambiental em Microbacias hidrográficas. In: GUERRA, A. J. T.; SILVA, A. S. d.; BOTELHO, R. G. M. Erosão e conservação dos solos. Rio de Janeiro: Bertrand Brasil, 1999.

BRASIL. Congresso Nacional. Lei n⿳0 9.433, de 8 de janeiro de 1997: política nacional de recursos hídricos. Disponível em $<$ http://www.planalto.gov.br/ccivil_03/leis/L9433.HTM>. Acesso em novembro de 2013.

CÁTEN, A.; DALMOLIN, R. S. D.; RUIZ, L. F. C.; SEBEM, E.; PEREIRA, R. S. Pedometria aplicada à predição de classes de solos utilizando de regressões logísticas múltiplas. In: Simpósio Brasileiro de Sensoriamento Remoto, XIV, 2009, Natal. Anais... Natal: INPE, p. 25-30, 2009.

CHAGAS, C. S. Mapeamento digital de solos por correlação ambiental e redes neurais em uma bacia hidrográfica no domínio de mar de morros. Viçosa, 2006. 223p. (Doutorado -Universidade Federal de Viçosa - UFV.

CHRISTOFOLETTI, A. Geomorfologia Fluvial. São Paulo: Edgard Blücher, 1980. 313 p.

DIKAU, R. The application of a digital relief model to landform analysis in geomorphology. In: RAPER, J. (Ed.). Three-dimensional applications in geographic information systems. New York: Taylor and Francis, p.51-77, 1989.

FRANKLIN, S. E., and D. PEDDLE, 1987, Texture analysis of digital image data using spatial cooccurrence, Computers \& Geosciences. 13(3): 293-311.

GALLANT, J. C.; WILSON, J. P. Primary topographic attributes. In: WILSON, J. P.; GALLANT, J. C. (Eds.). Terrain Analysis: Principles and applications. New York: John Wiley, p.51-85, 2000.

GUERRA, A. J. T. e CUNHA, S. B. da. Geomorfologia - Exercícios, Técnicas e Aplicações. Rio de Janeiro: Ed. Bertrand Brasil, 1996.

GUERRA, A. J. T. e CUNHA, S. B. da. A questão ambiental - Diferentes abordagens. Rio de Janeiro: Ed. Bertrand Brasil, 2003.

GUERRA, A. T. e GUERRA, A. J. T. Novo dicionário geológico-geomorfológico. 5 ed. Rio de Janeiro: Bertrand Brasil, 2005.

HORN, B. K. P. Hill shading and the reflectance map. Proceedings of the IEEE, n. 69, v. 01, p. 14-47, 1981.

HUTCHINSON, M. F. A new procedure for gridding elevation and stream line data with automatic removal of spurious pits. Journal of Hydrology, 106, 211-232, 1989.

HUTCHINSON, M. F. A locally adaptive approach to the interpolation of digital elevation models. In: International Conference/Workshop on Integrating GIS and Environmental Modeling, National Center for 
Geographic Information and Analysis. 3. 1996, Santa Bárbara. Proceedings... Santa Bárbara: University of California, 1996. CD-RON.

HUTCHINSON, M. F. Adding the Z dimension. In: WILSON, J. P.; FOTHERINGHAM, A.S. The handbook of geographic information science. 1. ed.Blackwell Publishing Ltd. 2008. p. 144-168.

IPPOLITI, G. A.; COSTA, L.M.; SCHAEFER, C. E.G. R.; FERNANDES FILHO, E. I.; GAGGERO, M. R.; SOUZA, E. Análise digital do terreno: ferramenta na identificação de pedoformas em microbacias na região de "Mar de Morros" (MG). Revista Brasileira de Ciência do Solo, v.29, p.269-276, 2005.

IWAHASHI, J.; PIKE, R. J. Automated classifications of topography from DEMs by an unsupervised nested-means algorithm and a three-part geometric signature. Geomorphology 86(3-4): 409-440, 2007.

MACMILLAN, R. A. e SHARY, P. A., Chapter 9 Landforms and landform elements in geomorphometry. In: HENGL, T. e REUTER, H. I. (eds), Geomorphometry-Concepts, Software, Applications. Developments in Soil Science, vol. 33, Elsevier, Amsterdam, 2009. Pag. 227-254.

McBRATNEY, A. B.; MENDONÇA-SANTOS, M. L.; MINASNY, B. On digital soil mapping. Geoderma, v. 117, p. 3-52, 2003.

MOORE, I. D.; GESSLER, G.A.; PETERSON, G.A. Soil attribute prediction using terrain analysis. Soil Science Society of America Journal, v.57, p.443-452, 1993.

MOORE, I.D., GRAYSON, R.B., LADSON, A. R. Digital terrain modeling: A review of Hydrological, geomorphological and biological applications. Hydrological Processes, v. 5, p. 3-30, 1991.

MUÑOZ, V. A. Análise geomorfométrica de dados SRTM aplicada ao estudo das relações solo-relevo. Instituto Nacional de Pesquisas Espaciais, São José dos Campos, 2009. 112p. (INPE-15796-TDI/1531). Dissertação (Mestrado em Sensoriamento Remoto). - Instituto Nacional de Pesquisas Espaciais.

PENNOCK, D. J. Terrain attributes, landform segmentation, and soil redistribution. Soil and Tillage Research 69 (1-2), 15-26, 2003.

SANTOS, R. F. dos. Planejamento Ambiental: teoria e prática. São Paulo: Oficina de Textos, 2004.

SCHMIDT, J., DIKAU, R. Extracting geomorphometric attributes and objects from digital elevation models - semantics, methods, future needs. In: Dikau, R., Saurer, H. (Eds.), GIS for Earth Surface Systems Analysis and Modelling of the Natural Environment. Schweizbart'sche Verlagsbuchhandlung, pp. 153-173, 1999.

SHARY, P.A., SHARAYA, L.S., MITUSOV, A.V. Fundamental quantitative methods of land surface analysis. Geoderma 107 (1-2), 1-32, 2002.

SILVEIRA, C.T.; SILVEIRA, R.M.P. Classificação geomorfométrica de unidades morfológicas do relevo no estado do Paraná obtida de atributos topográficos e árvore de decisão. Anais do XV Simpósio Brasileiro de Geografia Física Aplicada. Vitória/ES. 2013.

SILVEIRA, C. T. OKA-FIORI, C.; SANTOS, L. J. C; SIRTOLI, A. E.; SILVA. Pedometria apoiada em atributos topográficos com operações de tabulação cruzada por álgebra de mapas. Revista Brasileira de Geomorfologia, v.13, n.2, p.125-137, 2012.

SILVEIRA, C. T. OKA-FIORI, C.; SANTOS, L. J. C; SIRTOLI, A. E.; SILVA, C. R.; BOTELHO, M. F. Soil prediction using artificial neural networks and topographic attributes. Revista Geoderma 195-196, p. 165-172, 2013.

SIRTOLI, A. E.; SILVEIRA, C. T.; MONTOVANI, L. E.; SIRTOLI, A. R. A.; OKA-FIORI, C. Atributos do relevo derivados de modelo digital de elevação e suas relações com solos. Scientia agraria, v.9, n.3, p.317-329, 2008.

SPEIGHT, J.G. Parametric description of landform. In: Stewart, G.A. (Ed.), Land Evaluation: Papers of a CSIRO Symposium. Macmillan, Melbourne, pp. 239-250, 1968.

VALERIANO, M. M. Curvatura vertical de vertentes em microbacias pela análise de modelos digitais de elevação. Revista Brasileira de Engenharia Agrícola e Ambiental, Campina Grande, v.7, n.3, p.539-546, 2003.

VALERIANO, M. M.; CARVALHO JÚNIOR, O, A. Geoprocessamento de modelos digitais de elevação para mapeamento da curvatura horizontal em microbacias. Revista Brasileira de Geomorfologia, v 4, n.1, p.17-29, 2003. 
VELOSO, A. A importância do estudo das vertentes. Geographia, v. 4, n. 8, p 1-5, 2002.

WILSON, J. P.; GALLANT, J. C. Digital terrain analysis, chapter 1. In: WILSON, J. P.; GALLANT, J. C. (Eds.). Terrain analysis: principles and applications. New York: John Wiley \& Sons, p.1-27, 2000.

XAVIER DA SILVA, J. Geomorfologia e Geoprocessamento. In: GUERRA, A. J. T.; CUNHA, S. B. da. Geomorfologia uma atualização de bases e conceitos. Rio de Janeiro: Bertrand Brasil, 2005.

ZEVENBERGEN, L.W.; THORNE, C.R. Quantitative Analysis of Land Surface Topography. Earth Surface Processes and Landforms, v.12, p.47-56, 1987.

Submitted may 2016 Accepted june 2016 
TRENTIN, R.; ROBAINA, L. E. S. 